\title{
Quartz Veins Characteristics and Au Mineralization Within the Batouri Au District, East Cameroon
}

\author{
Mero Yannah ${ }^{1, ~ *, ~ C h e o ~ E m m a n u e l ~ S u h ², ~ M b o u d o u ~ G e r m a i n ~ M . ~ M b o u d o u ~}{ }^{2}$ \\ ${ }^{1}$ Institute of Geological and Mining Research, Yaounde, Cameroon \\ ${ }^{2}$ Department of Geology, University of Buea, Buea, Cameroon
}

Email address:

merotumi@gmail.com (M. Yannah)

\section{To cite this article:}

Mero Yannah, Cheo Emmanuel Suh, Mboudou Germain M. Mboudou. Quartz Veins Characteristics and Au Mineralization Within the Batouri Au District, East Cameroon. Science Research. Vol. 3, No. 4, 2015, pp. 137-149. doi: 10.11648/j.sr.20150304.12

\begin{abstract}
The Batouri south Au district of East Cameroon is hosted by biotite-amphibole meta-granites that belong to the Pan-African group of Pre-to Syn $\mathrm{D}_{1}$ and $\mathrm{D}_{2}$ Neoproterozoic granitoids. Hydrothermal activity and Au mineralization in this area is greatly enhanced by the presence of fractures, foliations, faults (sinistral) and vein splays hosted within a foliated metagranite basement. Thirteen samples of $1.00 \mathrm{~kg}$ each of quartz vein were crushed and panned for Au-grain recovery. Fire Assay geochemistry was used to analyze eighteen samples for Au. Field results identified foliated and non-foliated GQV/BQV quartz vein varieties. The mineralization style in the area is mainly by fracture filled. Disseminated Au is common in the weathered wall rock envelop associated with mineralized veinlets. Au-grade from fire assay geochemistry varies from $\sim 0.056 \mathrm{~g} / \mathrm{t}$ to 2.844 $\mathrm{g} / \mathrm{t}$ similar to 3-4 g/t Au-grade from field analysis associated with the GQV veinlets and weathered wall rock. The highest Augrade was obtained from the foliated variety of GQV $\left(\mathrm{QV}_{2}\right)$. Recovered Au-grains varied in shape and sizes $(102-392 \mu \mathrm{m})$.
\end{abstract}

Keywords: Quartz Veins, Au Mineralization, Batouri South-Cameroon

\section{Introduction}

Quartz vein systems in regions that have experienced deformation remain the main depository for primary $\mathrm{Au}$ [e.g. 1-2]. Such deformation occurs in stages and the fluxes of hot fluids from the subsurface (hydrothermal) into the resulting structures also follow the sequence of deformation. These fluids eventually precipitate material into these structures to form lodes and veins that differ in their characteristics [2-6]. Based on the pattern of deformation, different types of veins are produced including fault-fill-veins, extensional-veins and stock work-like veins $[7,8]$. The composition of the fluids also determine the mineralogy of the formed veins such as tourmaline-Au veins, quartz-Au veins, epidote-sericite-Au veins and sulfide-Au veins [7]. However, most Au- bearing veins are usually the quartz veins type of polymetallic character [9, 10 - 13]. In quartz vein systems, different textural characteristics can be observed. Some of these textures are usually associated with the ore zones (mineralized veins) while others are linked to the barren zones [7]. Some of the mineralized textures include overprinting and modification textures including phantom veins, ribbon and /or brecciated quartz, laminated quartz and comb quartz textures [7].

In addition to textures and structures, quartz vein systems commonly show alteration characteristics known as wall rock alteration $[3,14,15]$. The alteration is commonly related to hydrothermal processes and could also be formed from supergene activity. Generally, the boundary between alteration zones is often sharp [7, 16]. Most often, the intensity of the alteration envelope correlates positively with the thickness of the veins and veinlets [3]. In most cases of $\mathrm{Au}$ exploration, grade is easily assessed by crushing a quantity of the sample, weighing and panning to obtain the concentrate from which the Au-grains if present, can easily be recovered and weighed [e.g.17]. Therefore, vein systems (quartz veins) constitute a major tool in the study and understanding of hydrothermal processes as well as the geochemistry of ore deposits that serves as a guide in mineral exploration [e.g. 7, 17, 18-21,].

\section{Location and Geology of the Study} Area

The Batouri gold district is found in the East Region of Cameroon bordered to the west by Bertoua the regional 
capital and to the east by the Central African Republic. Geographically, the study area (Batouri south) consists of a semi tropical forest wet climate, characterized by gentle hills $(\approx 600 \mathrm{~m}$ to $900 \mathrm{~m}$ high $)$. This area shows a thick soil profile $(\approx 30 \mathrm{~m}$ ) that belongs to the Ferralitic class derived from the weathering of the granitoid basement rocks. These soils are highly leached leading to the development of a broad surface duricrust that hampers agricultural activities and artisanal mining. The study was limited around the Dimako and Kambele mining camps (Fig 1). Geologically, Batouri south belongs to the Pan African granitoids group of rocks whose emplacement spanned from the start of tectonic deformation to the late uplift of the Central African Orogenic Belt [22]. According to [23], the Pan-African domain of north western Cameroon shows complexity and diversity in the structural network. [23] Also identified three main geotectonic units belonging to the Pan-African: the Poli Group, the Adamawa domain and the Yaoundé Group. These Pan African granitoids cross-cut both the schist belts and the Paleoproterozoic high-grade metamorphic complexes of the region and are broadly made of Pre-to-Syn-D1 granitoids (calc-alkaline metadiorites and Metagranodiorites), 2) SynD2 granitoids (plutons of S-types granites and porphyritic granites and granodiorites), 3) Post-tectonic granites [22]. [24] Indicated that the Central Cameroon Shear Zone (CCSZ) system is identified as a syn-D3 structure, characterized by thick mylonitic layers whose bands are defined by S1 and S2 foliations. This work focuses on Au-quartz vein system in the Batouri South Au district (Fig. 1). The general objective is to contribute to $\mathrm{Au}$ exploration and enhance the understanding of hydrothermal processes in $\mathrm{Au}$ mineralization in East Cameroon which would be realized by: the determination of structural and field characteristics of quartz veins, identifying evidences of wall rock alteration within and around quartz veins; assessment of Au-grade from the crush and pan technique, and also by fire assay geochemistry.

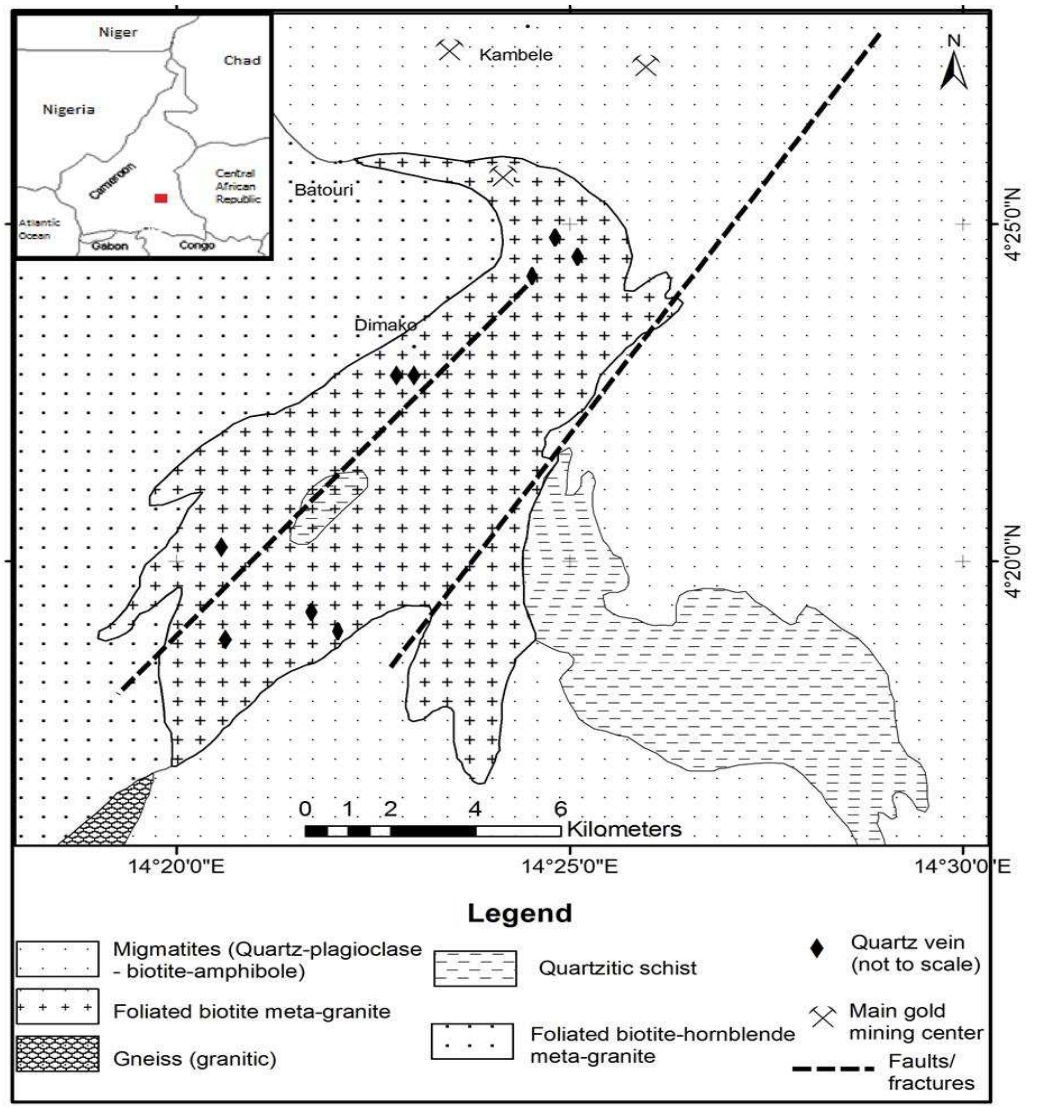

Figure 1. Geological map of Batouri Au district and associated mining camps (modified from Suh 2008).

\section{Materials and Methods}

This study was carried out in conjunction with the exploration phase of Africa Aura Resources Ltd (AAR) exploration programme. In this regard it serves as a contribution to the ongoing regional exploration survey of the Batouri Au district. During this study, investigated sites which constituted mining pits hosted by granitoids basement were identified with the use of the regional soil grid map. These pits were all artisanal mining pits randomly distributed and also occurred in clusters at different parts within the study area. It was realized that within most of the pits, the quartz veins were already completely extracted leaving behind tunnels especially with the mineralized veins (Auquartz veins). Most of the pits were abandoned and measured between 4-6 $\mathrm{m}$ depth, and at least 4 x $5 \mathrm{~m}$ wide.

a). Field surveying technique

Quartz vein and associated weathered margins exposed in pits constitute the main geological features investigated. Within every located mining pit, the vein(s) were identified 
and described using attributes like change in color, texture, dimensions and structural orientations (lineation). Two selected pit walls with quartz veins showing evidence of wall rock alteration were described, logged and sampled systematically. Quartz veins were further logged separately by identifying the changes in their internal fabric: texture, structure, mineralogy, color and dimensions of each domain. Quartz vein description was done following the pattern presented in the flow chart (Fig. 2). The information obtained from logging was plotted on graph sheets and further digitized using MapInfo Professional 8.3 software (Fig. 5, 7ai $\&$ bii). Sampling of the veins and weathered wall rock material was also carried out following the same pattern used in logging. A total of thirty-one samples were collected. Thirteen of the samples used for field analysis weighed $1 \mathrm{~kg}$ each and were made up of quartz vein material only. The eighteen remaining samples collected for laboratory analysis were a mixture of quartz veins and weathered wall rock material obtained by logging and each equally weighed $1 \mathrm{~kg}$. Samples were logged from east to west on two pit walls.

b). Physical analysis

The thirteen quartz vein samples were crushed in powder using a metallic bowl and pestle. The powders were panned to obtain the concentrates made up of the heavy mineral fraction. These concentrates were initially observed in the field using a hand lens for the presence of Au. After the field observation, the concentrates were then sun dried and further observed under a binocular microscope from which visible Au-grains were handpicked and weighed using a sensitive electronic balance in the laboratory at the University of Buea, Cameroon to determine the grade of Au.

c). Geochemical analysis

In the OMAC Commercial Laboratory, Dublin, $50 \mathrm{~g}$ of each pulverized sample were analyzed by fire assay geochemistry using lead collection and AA finish, In-house method. The detection limit for $\mathrm{Au}$ was set at $2 \mathrm{ppb}$. Randomly selected samples were analyzed twice for quality control. In-house blanks were used to correct for any aliquot impurity. International standards used in calibrating the equipment followed procedures indicated in [25]. Ore and scanning electron microscopy was used to analyze for minerals associated within quartz veins. To investigate these associations, a selected quartz vein sample was divided into three pieces in the laboratory. One piece was cut and polished to obtain thin sections which were subsequently studied under an ore microscope using reflected light. The second part was crushed and panned in the laboratory to obtain the heavy mineral concentrate and further observed under a Scanning Electron Microscope (SEM) fitted with an Energy Dispersive Spectrometer (EDS) following procedures described in [26]. The SEM identified the morphology of $\mathrm{Au}$ grains while the EDS provided geochemical patterns reminiscent of the chemical composition of each phase identified. The third part served as back up.

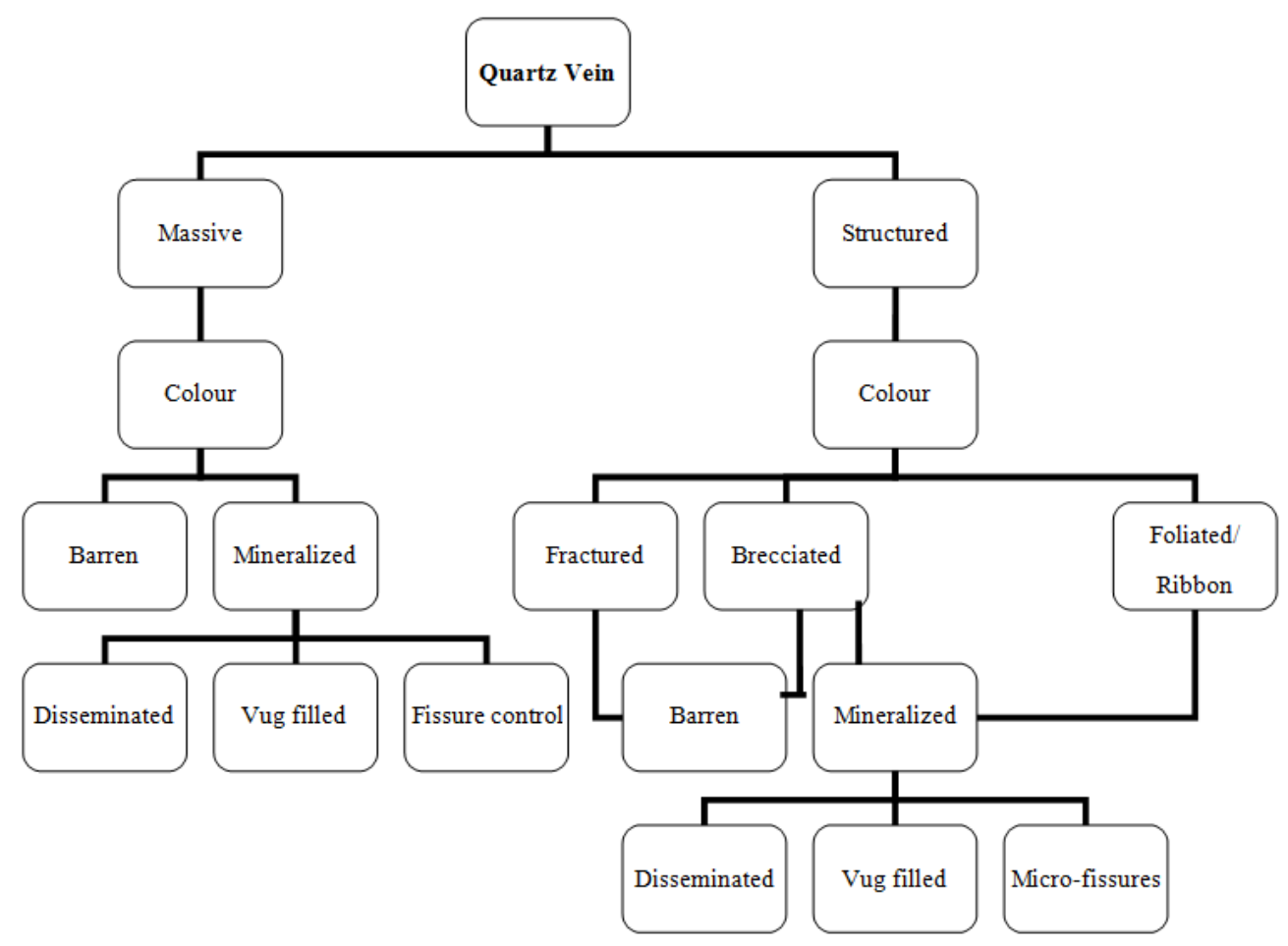

Figure 2. Flow chart describing quartz veins systems in the Batouri Au district.

\section{Results and Discussion}

\subsection{Structural Control}

The veins of the Batouri south Au district are hosted by a foliated meta-granite and show variable orientations controlled by foliations and sinistral faults. Cross-cutting relationships among veins were observed implying different stages of veins emplacement in the area. The early formed veins trend mostly NNE-SSW, NE-SW NNW-SSE which are 
being displaced in centimetric scale by the late ENE-WSW trending veins. Based on reports from [27], the late forming veins are probably associated with the $D_{3}$ deformation. The early formed veins have shallow dips between $15^{\circ}-35^{\circ}$ as opposed to the late forming counterpart with high dips of $>70^{\circ}$. A similar difference among the cross-cutting veins was observed in texture and $\mathrm{Au}$ mineralization. The later consist mainly of the mineralized veins with both categories occurring in spatial association. Such structural relationships are common in orogenic zones, particularly in shear related deformation [e.g.16, 28, 29]. According to [30], subsequent plutonism or metamorphism may cause the reactivation of these structures. A plotted stereonet for six selected veins (Fig. 3) indicate a NNE-SSW and NNW-SSE orientation for the veins. [27] Indicated that structures from $D_{1}$ and $D_{2}$ deformation host most mineralized veins in Batouri area while the $\mathrm{D}_{3}$ event saw the emplacement of the barren quartz variety having a major ENE-WSW trend. Apparently, a large population of the mineralized veins had already been extracted by artisanal miners by tunneling and these tunnels mostly trend NNE-SSW, NE-SW and NW-SE. Fracture cleavage and mylonitic foliations occur as the main planar features with the quartz mylonites showing intense stretching and fragmentation surrounded by dark hematite seams. Both foliations are concordant to the strike of the veins and are often cross-cut obliquely and perpendicularly by fractures. The presence of sinistral strike-slip faults; slickenside straie, intense foliation as well as mylonitic foliation collectively suggest intense shearing within an orogenic tectonic setting for the veins emplacement [31]. The laminated margins along veins also suggest localized shearing probably due to high fluid pressure that subsequently promoted fracturing [31, 32]. Nevertheless, shear movement alone cannot fully explain the system of evolution in these veins since some of the veins rather show intense fracturing. However, most mesothermal orogenic Au-regions around the world have experienced multiphase deformation similar to what was observed in the Batouri area [e.g. 4, 5, 8, 31, 32]. The spatial association of brittle and ductile structures (fractures, foliations, lineations) genetically suggests similar stress conditions of formation [33].

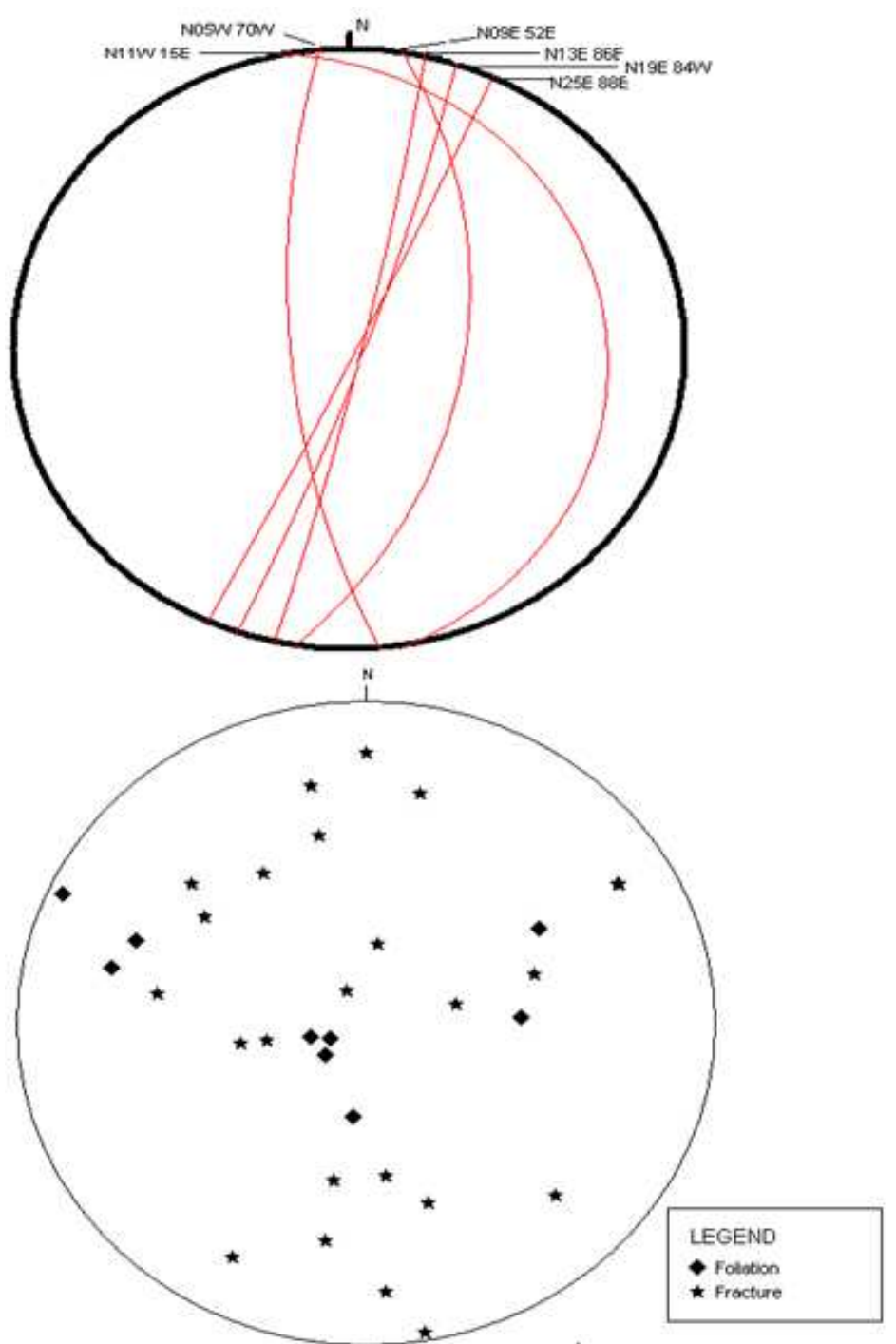

Figure 3. Stereographic plots of structural data for some veins and measured fractures. (a): beta diagram for barren and mineralized quartz veins showing (a) east dominant dip direction with . (b): $\pi$ diagram showing irregular distribution of fractures and foliations in veins. 
(a)
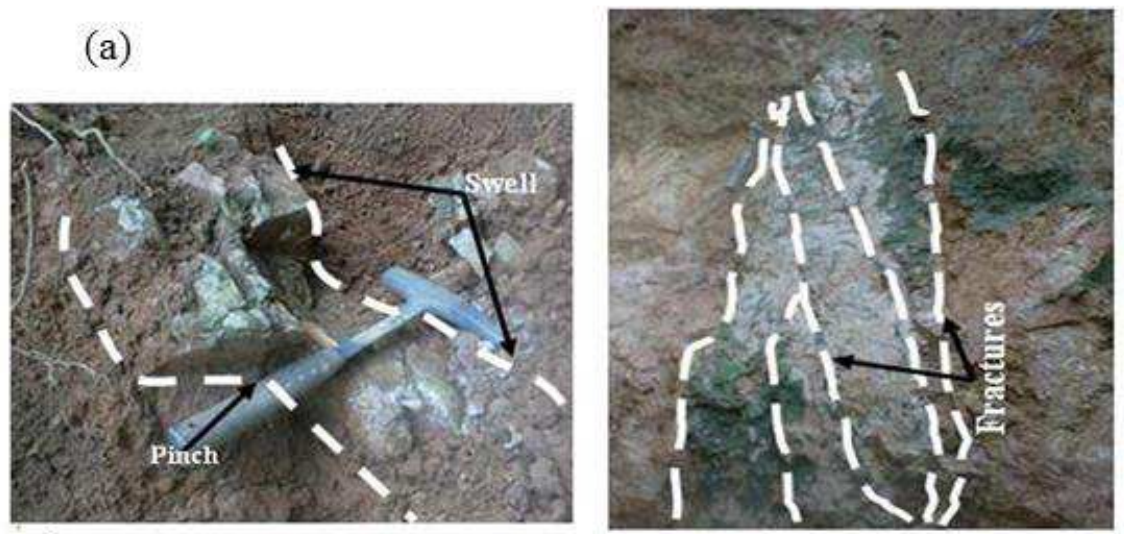

i

ii

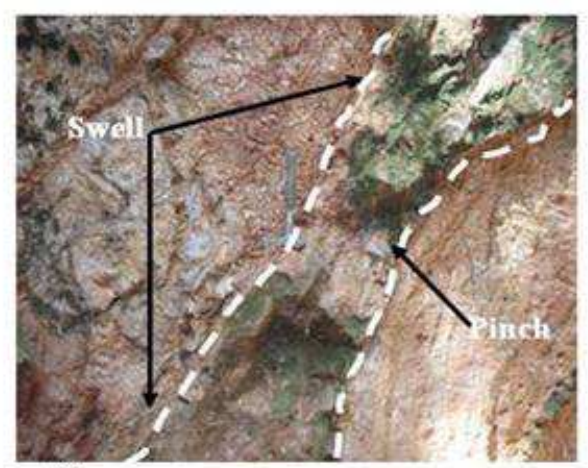

iii

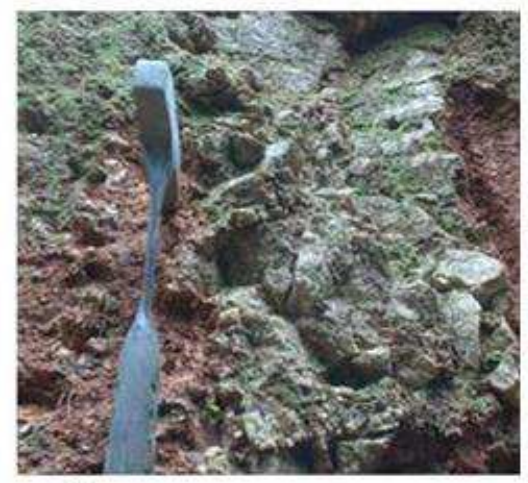

iv

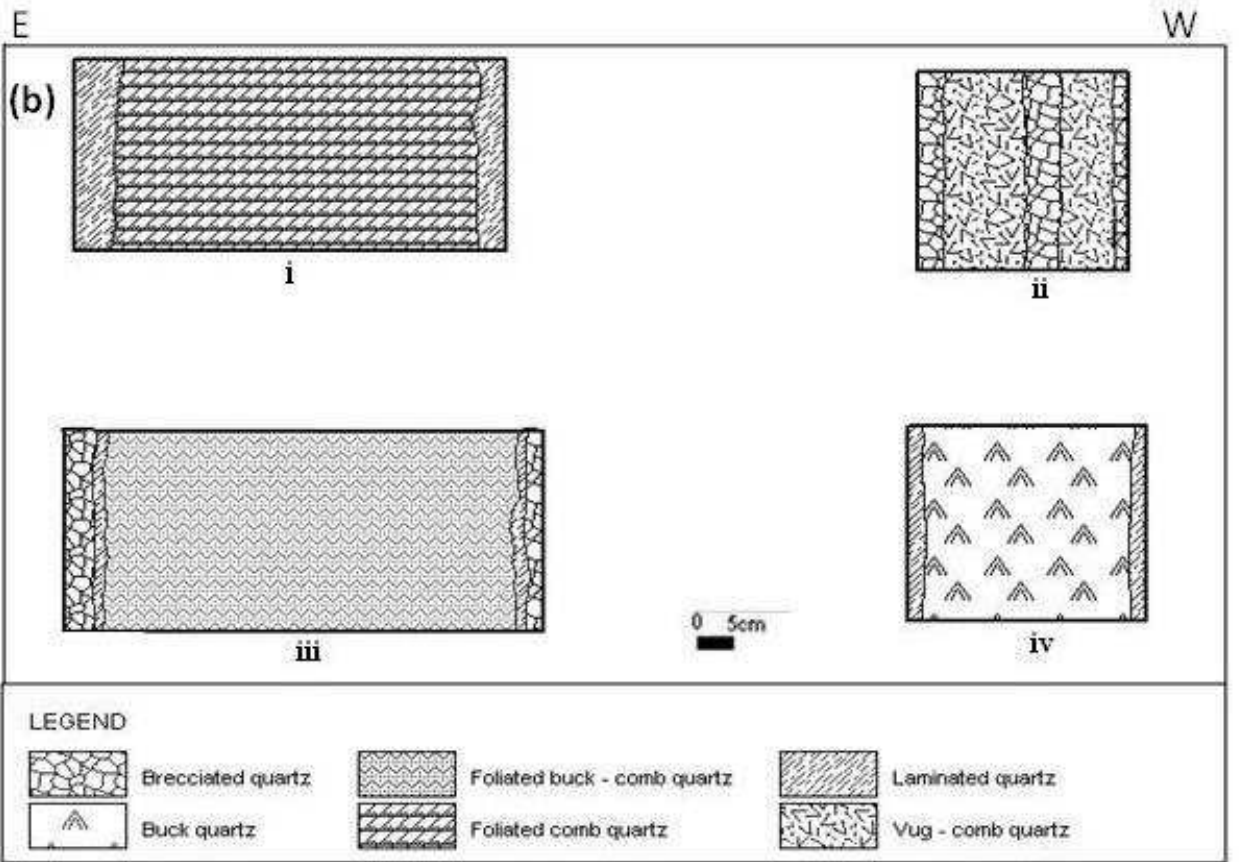

Figure 4. Batouri GQV and BQV showing a) field photographs of a foliated (ai) and a non-foliated anastomosed GQV (aii) indicated by the orientation of the fractures on the surface and b) cross sections of GQV/BQV veins showing textural zoning (bi) foliated GQV depicted in 4ai, (bii) non-foliated GQV depicted in Fig. 4aii. (iii) Foliated BQV depicted in 4 aiii (iv) non-foliated BQV as depicted in 4aiv (note the intensity of fracturing).

\subsubsection{Au- Bearing Quartz Veins (GQV)}

The investigated veins in this area composed of quartz (70$\left.90 \mathrm{vol}^{\circ} \%\right)$ sulphide minerals $\left(10-20 \mathrm{vol}^{\%} \%\right)$ and oxides $(5-25$ $\left.\mathrm{vol}^{\%} \%\right)$. These quartz veins were grouped into two categories: Au-Bearing quartz veins (GQV) and the Barren Quartz Veins
(BQV) (Fig. 4aiii, a iv \& 5). The GQV veins are the most common in this area. However, this study was able to identify just a few (4) reason being that most of them have been excavated by the local miners in search for Au. The GQV occur both as foliated and non-foliated varieties (Fig. 4ai, aii, bi \& bii). The foliated variety have very low dip $(<$ 
$25^{\circ}$ ) to the west. These GQV are also fractured and have an average thickness of $32 \mathrm{~cm}$ mostly with a characteristic pinch and swell outline. The vein margins are slightly laminated with weathered wall rock slivers interleaved with stretched quartz (Fig. 4bi). Quite commonly, the GQV bear saccharoidal pink to brown quartz. Along fractures, the quartz is stained with purplish hematite coating. Comb textures are also common within these foliated varieties. The non-foliated GQV veins on the other hand, have higher dips $\left(70^{\circ}-80^{\circ}\right)$ to the east and are anastomosed (Fig. 4aii). These veins are smaller $(6 \mathrm{~cm}$ on average) and are highly fractured.

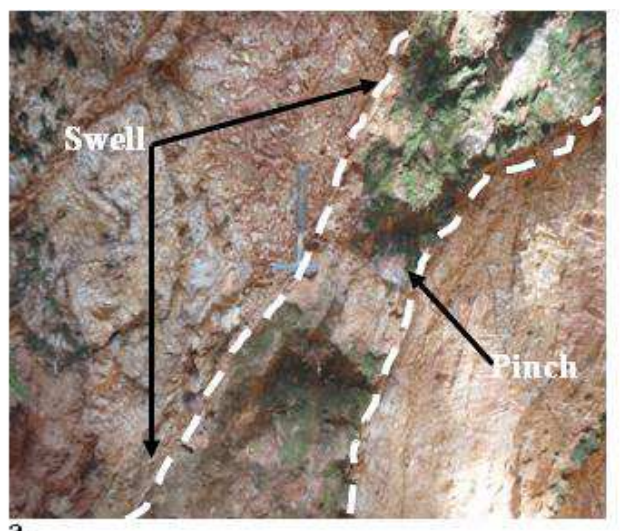

a.

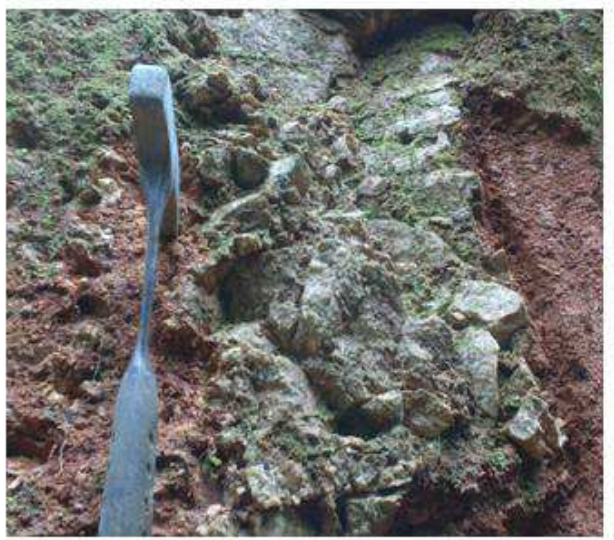

c.

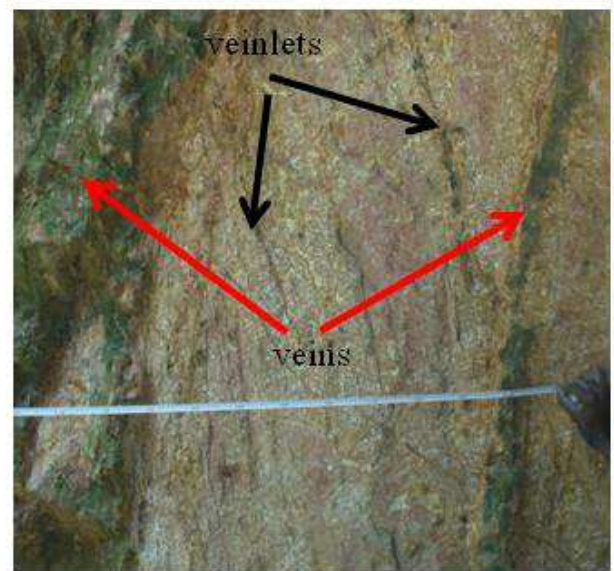

The internal structure of the veins depicts textural zoning (Fig. 4bii) with brecciated bands sandwiched by nonbrecciated quartz variety. The quartz breccia consists of fragments of smoky and buck quartz cemented by dark hematite seams. Poorly developed comb textures and vugs are common within the non-brecciated zones. Pyrite (Sulphide minerals) together with hematite, Covellite and chalcocite occur within the brecciated bands.

\subsubsection{Barren Quartz Veins (BQV)}

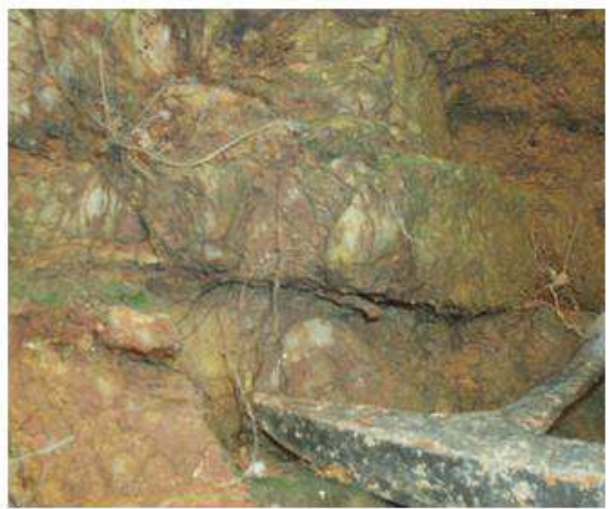

b.

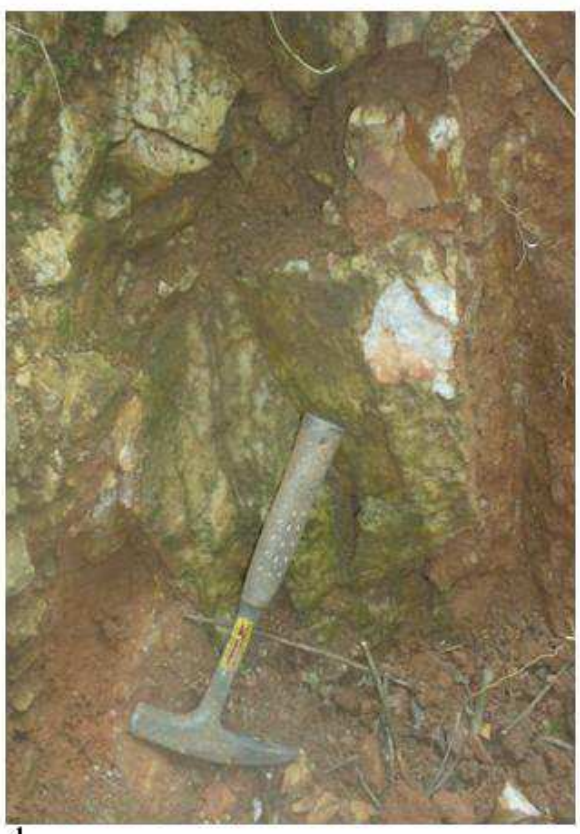

d.

e.

Figure 5. Field photographs of foliated and non-foliated BQV (a) foliated pinch and swell (b) foliated blocky pinch and swell (c,) brecciated pinch and swell (d) non-foliated smoky quartz vein (e) veins with associated veinlet. 
The BQV veins show a characteristic pinch and swell outline dipped to the east. These veins fractured and also made of the foliated and non-foliated varieties (Fig. 4aiii, iv, biii, biv \& 5 a-e). The foliated variety vary in width from $7 \mathrm{~cm}$ to $\sim 60 \mathrm{~cm}$. Based on the texture, the veins are weakly brecciated at the margins and become progressively laminated towards the center (Fig. 4biii). Foliated buck and comb quartz forms the center part of the veins. Quartz crystals defining the comb textures occur as long $(0.3-2 \mathrm{~cm})$ euhedral crystals. The color of the quartz varies from milky white at the center to rusty brown along the fracture and foliation planes. The non-foliated variety appeared to be more common showing intensely fracturing (Fig. 5b-d). Both saccharoidal and buck quartz are present showing white to rusty brown color. Vugs and comb textures present are partially filled by quartz, hematite and sulphide minerals. Quartz crystals occur as subhedral to euhedral (hexagonal), exhibiting variable grain sizes with no preferential orientation. However, quartz grains in the comb show no sign of deformation but crystals crisscrossing each other. Generally along both vein categories, their associated quartz veinlets are oriented concordant to the veins. The mineralogical property of the veinlets is similar to that of the corresponding veins (Fig. 5e). According to [34], open space textures (vugs) with euhedral quartz crystals in veins suggest a situation where fluid pressure during vein formation has been equal or exceeded lithostatic conditions [35], as the preservation of such textures maybe ascribed to low confining pressure [36-38].

\subsection{Alteration and Au Mineralization}
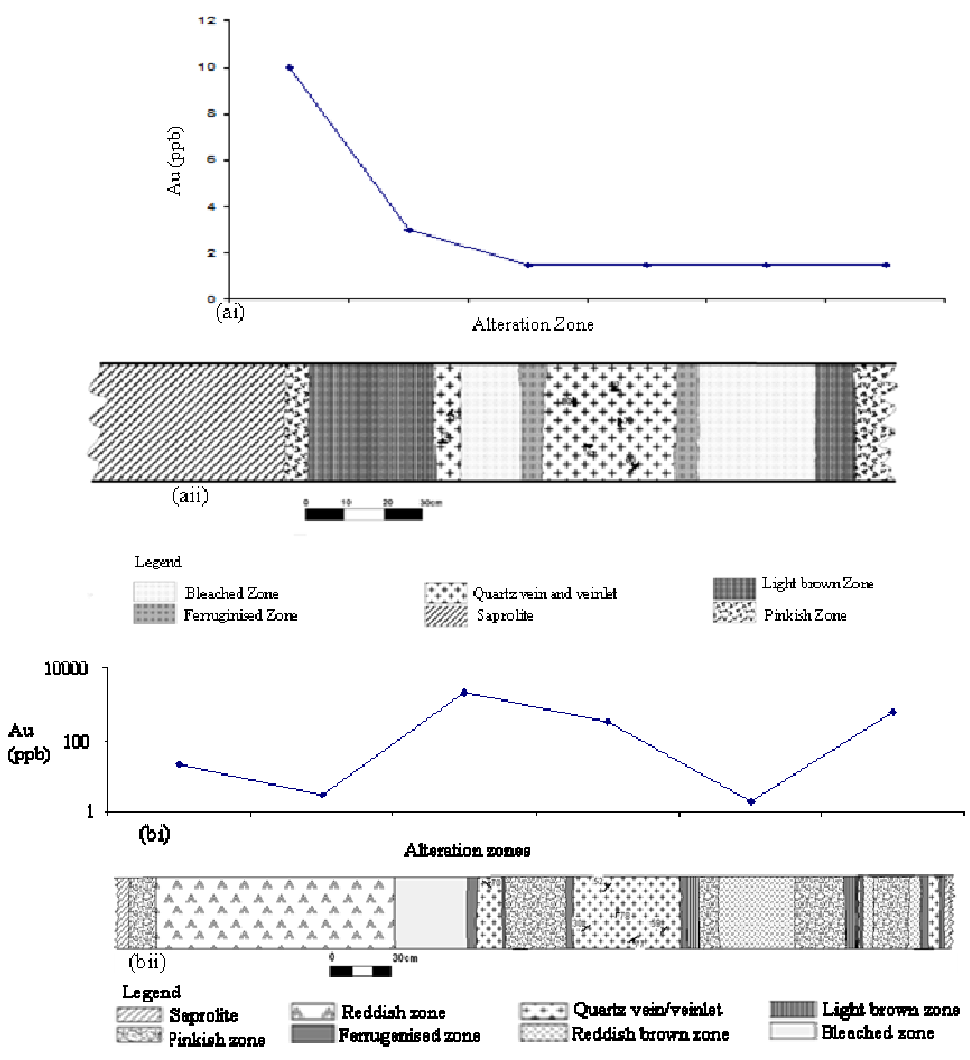

Figure 6. Zonation pattern along veins logged from East-West (a i) variation of Au concentration within the different zones on pit wall I (aii) weathered wall rock zonation along veins on pit wall I (bi) variation of Au concentration within the different zones on pit wall II (b ii) weathered wall rock zonation along veins on pit wall II.

The study area has a very thick soil profile $(\geq 30 \mathrm{~m})$ that provides limited access to the fresh meta-granitic (granitoid) basement. However, the relicts of hydrothermal wall rock alteration were observed within the regolith in mining pits. A symmetric alteration envelops (Fig. 6a \& b) surrounding veins in this area was observed and suggests situation of alteration process that commences the moment hydrothermal fluid entered the host structures [e.g.7]. The alteration halos observed show lateral zoning with partially preserved texture of the weathered host rock. This was determined mainly by changes in mineralogy, color, texture and structure along and within the veins. Four main alteration zones were identified: ferruginized zone (FZ) that encloses the vein (Fig. 6). This zone grades out into a bleached zone (BZ), then to a light brown zone (LBZ) that is bordered by an outer pinkish zone (PZ) (Fig. 6a). The FZ occurs as a thin dark brown, well silicified and having a characteristic clayey texture. The BZ contains sugary quartz often associated with the GQV 
(foliated and non- foliated). The bleaching may be due to Kfeldspars replacement by residual Ti-oxide [16] or sericite [39]. According to [17], the bleached zone stands as a major indicator for hydrothermal alteration, even though it usually does not contain Au. In situation where two or more veins occur together, (Fig. 6b), the BZ is absent or replaced by the reddish-brown or a light brown zone. Even though geochemical analysis was not performed on the parent metagranitic host rock, the gradual decrease and eventual absence of $\mathrm{Au}$ within the outer weathered wall rock envelop along GQV gives a strong indication that the parent rock itself lacks or is weakly mineralization.

\subsubsection{Ore Mineralogy and Au Geochemistry}

From the thirteen quartz samples analyzed from the field technique, three of the samples contain $\mathrm{Au}$ (Table 1). Amongst these three, two of the veins gave significant $\mathrm{Au}-$ grade which includes: quartz vein one $\left(\mathrm{QV}_{1}\right)$ and two $\left(\mathrm{QV}_{2}\right)$ that yielded $4 \mathrm{~g} / \mathrm{t}$ and $3 \mathrm{~g} / \mathrm{t}$ of Au respectively. In these veins, $\mathrm{Au}$ occurs in close association with hematite, pyrite, and chalcopyrite. For the geochemical analysis, varying Augrades were obtained using fire assay geochemistry. $\mathrm{QV}_{2}$ gave the highest Au-grade of about $2.84 \mathrm{~g} / \mathrm{t}$ and $0.83 \mathrm{~g} / \mathrm{t}$ from the associated veinlets (Table 2). $\mathrm{QV}_{1}$ also gave $1.99 \mathrm{~g} / \mathrm{t}$ of $\mathrm{Au}$ with about $0.32 \mathrm{~g} / \mathrm{t}$ obtained from the veinlets associated with reddish-brown zone material. Meanwhile, relatively low grades $(<0.001 \mathrm{~g} / \mathrm{t})$ were obtained from most weathered wall rock material. [27] Reported Au-grades in quartz vein between $0.04 \mathrm{~g} / \mathrm{t}->30 \mathrm{~g} / \mathrm{t}$ and the fresh wall rock between $0.4-18.5 \mathrm{~g} / \mathrm{t}$. The Au-grade obtained for $\mathrm{QV}_{1}$ and $\mathrm{QV}_{2}$ (table 2; ADBREG-03 and 04) differed slightly from that obtained from panning (table 1). Reasons could be due to the differences in the sample sizes used in both analyses.

Photomicrographs obtained from polished sections for $\mathrm{QV}_{1}$ and $\mathrm{QV}_{2}$ show aspects of hydrothermal activity and ore mineralization (Fig. 7a, b). The sulphide minerals in $\mathrm{QV}_{1}$ occur as subhedral to euhedral crystals buried in a finegrained quartz matrix (Fig. 7a). Pyrite and chalcopyrite which occur as the most abundant sulphide were equally zoned. Covellite and chalcocine occur as part of the mineral associated with $\mathrm{Au}$ based on field observations. According to reports of [17] in this area, the covellite/chalcosite minerals are highly associated with $\mathrm{Au}$ ahead of chalcopyrite and pyrite. It is possible that these minerals resulted from supergene enrichment during which they were leached and reprecipitated. This is also supported by the occurrence of these minerals in association with colloidal hematite and clay minerals. Au was not visible in $\mathrm{QV}_{1}$ (Fig. 8a), however, Augrains in $\mathrm{QV}_{2}$ follow micro-fissures in the quartz crystal (Fig. $8 b)$.

Table 1. Au grade obtained from panning of equal amount of homogenized crushed quartz samples.

\begin{tabular}{|c|c|c|c|c|c|c|}
\hline Vein type & Location(UTM) & Vein Description & Weight panned & grains & Weight(g/kg) & $\operatorname{grade}(\mathrm{g} / \mathrm{t})$ \\
\hline $\mathrm{QV}_{1}$ & $\begin{array}{l}33 \mathrm{~N} 0426936 \\
0483780\end{array}$ & $\begin{array}{l}\text { Weathered, brecciated smoky quartz vein, oriented } \\
\text { N175E,70W }\end{array}$ & $1.00 \mathrm{~kg}$ & 4 & 0.004 & 4 \\
\hline $\mathrm{QV}_{2}$ & $،$ & $\begin{array}{l}\text { Weathered foliated saccharoidal quartz. Very rich in } \\
\text { hematite mineral. Oriented N169E, } 15 \mathrm{E}\end{array}$ & $1.00 \mathrm{~kg}$ & 20 & 0.003 & 3 \\
\hline $\mathrm{QV}_{3}$ & “ & $\begin{array}{l}\text { Foliated buck quartz, rich in pyrite and chalcopyrite. } \\
\text { Oriented N25E, } 88 \mathrm{E}\end{array}$ & $1.00 \mathrm{~kg}$ & 1 & - & - \\
\hline
\end{tabular}

Table 2. Fire assay geochemical data for Au concentration (ppb) in quartz veins and weathered wall rock samples from the Batouri Au district, East Cameroon.

\begin{tabular}{|c|c|c|c|c|c|}
\hline Sample $\mathbf{N}^{\mathbf{0}}$ & Sample Description & Location (UTM) & Grade (ppb) & Grade (g/t) & Replicate (ppb) \\
\hline ADBREG-01 & $\begin{array}{l}\text { Pinch and swell, foliated veinlets associated with } \mathrm{QV}_{1} \text {. Sample } \\
\text { consists of buck quartz with open space texture. }\end{array}$ & $\begin{array}{l}33 \mathrm{~N} 0426936 \\
0483780\end{array}$ & $<2$ & - & - \\
\hline ADBREG-02 & $\begin{array}{l}\text { Quartz sample obtained from splays. Sample is a mixture of } \\
\text { quartz and altered granitic weathered wall rock material along } \\
\mathrm{QV}_{2} \text {. }\end{array}$ & “ & 828 & 0.828 & - \\
\hline ADBREG-03 & $\begin{array}{l}\text { Quartz sample from a non-foliated quartz vein }\left(\mathrm{QV}_{3}\right) \text {. Vein } \\
\text { shows anastomosing structure, dipping west. }\end{array}$ & “ & 56 & 0.056 & - \\
\hline ADBREG-04 & $\begin{array}{l}\text { Quartz sample from a foliated quartz vein }\left(\mathrm{QV}_{2}\right) \text {. Sample } \\
\text { consist of saccharoidal quartz, rusty brown to purple in color }\end{array}$ & $\begin{array}{l}33 \mathrm{~N} 0426934 \\
0483789\end{array}$ & 2844 & 2.844 & - \\
\hline ADBRE-05 & $\begin{array}{l}\text { Moderately oxidized weathered wall rock material obtained } \\
\text { from a light brown zone within an alteration envelope along } \\
\mathrm{QV}_{4} \text {. }\end{array}$ & $\begin{array}{l}33 \mathrm{~N} 0427589 \\
0486462\end{array}$ & 3 & 0.003 & - \\
\hline ADBRE-06 & $\begin{array}{l}\text { Feldspatic weathered wall rock material obtained from a } \\
\text { pinkish zone within an alteration envelope along } \mathrm{QV}_{4} \text {. }\end{array}$ & “ & 10 & 0.010 & - \\
\hline ADBRE-07 & $\begin{array}{l}\text { Silicified weathered wall rock material from a bleached zone } \\
\text { along } \mathrm{QV}_{4}\end{array}$ & “ & $<2$ & - & - \\
\hline ADBRE-08 & $\begin{array}{l}\text { Weathered granitic wall rock material obtained from a } \\
\text { ferruginized zone along } \mathrm{QV}_{4} \text {. Sample is dark in color and } \\
\text { silicified. }\end{array}$ & “ & $<2$ & - & - \\
\hline
\end{tabular}




\begin{tabular}{|c|c|c|c|c|c|}
\hline Sample $\mathbf{N}^{0}$ & Sample Description & Location (UTM) & Grade (ppb) & Grade (g/t) & Replicate (ppb) \\
\hline ADBREG-09 & $\begin{array}{l}\text { Quartz material from vein }\left(\mathrm{QV}_{4}\right) \text { mixed with the associated } \\
\text { proximal thin ferruginized zone. }\end{array}$ & “. & $<2$ & - & - \\
\hline ADBREG-10 & $\begin{array}{l}\text { Quartz material from non-foliated quartz vein. sample consists } \\
\text { of comb and buck quartz with open space texture }\end{array}$ & “ & $<2$ & - & $<2$ \\
\hline ADBREG-11 & $\begin{array}{l}\text { Quartz material from veinlets mixed with reddish weathered } \\
\text { granitic wall rock material. }\end{array}$ & $\begin{array}{l}33 N 0426934 \\
0483789\end{array}$ & 2 & 0.002 & - \\
\hline ADBREG-12 & $\begin{array}{l}\text { Chipped sample from a non-foliated quartz vein dominantly } \\
\text { made up of buck quartz. Visible quartz crystals are common } \\
\text { and misorriented. }\end{array}$ & $\begin{array}{l}33 \mathrm{~N} 0426936 \\
0483780\end{array}$ & $<2$ & - & - \\
\hline ADBRE-13 & $\begin{array}{l}\text { Chipped sample from a foliated pinch and swell quartz vein. } \\
\text { Sample consists of comb quartz, buck quartz and have pen } \\
\text { space texture. }\end{array}$ & “ & 21 & 0.021 & - \\
\hline ADBRE-14 & $\begin{array}{l}\text { Oxidized weathered wall rock material obtained from reddish } \\
\text { saprolitic zone along } \mathrm{QV}_{1} \text {. }\end{array}$ & “ & 3 & 0.003 & - \\
\hline ADBRE-15 & $\begin{array}{l}\text { Oxidized granitic weathered wall rock material from reddish } \\
\text { zone along } \mathrm{QV}_{1} \text {. }\end{array}$ & “ & 1989 & 1.989 & - \\
\hline ADBRE-16 & $\begin{array}{l}\text { Quartz material from splay and associated weathered wall rock } \\
\text { material. }\end{array}$ & “ & 316 & 0.316 & - \\
\hline ADBRE-17 & $\begin{array}{l}\text { Chipped sample containing quartz from } \mathrm{QV}_{1} \text { and } \mathrm{QV}_{3} \text { dipping } \\
\text { west and east } \\
\text { respectively. Sample mixed with reddish altered granitic } \\
\text { material. }\end{array}$ & “ & 2 & 0.002 & - \\
\hline ADBRE-18 & $\begin{array}{l}\text { Chipped sample containing part of } \mathrm{QV}_{3} \text { and reddish-brown } \\
\text { altered granitic material. }\end{array}$ & “ & 582 & 0.582 & - \\
\hline
\end{tabular}

NB: Sample 01-18: obtained from three different investigated sites; ADBREG: are grabbed samples collected from quartz veins and veinlets. ADBRE: are samples collected by lateral channel chip across veins and associated weathered wall rock. Samples 13-18: were sampled indiscriminately across veins and weathered wall rock in an interval of about $63 \mathrm{~cm} \mathrm{E-W.}$
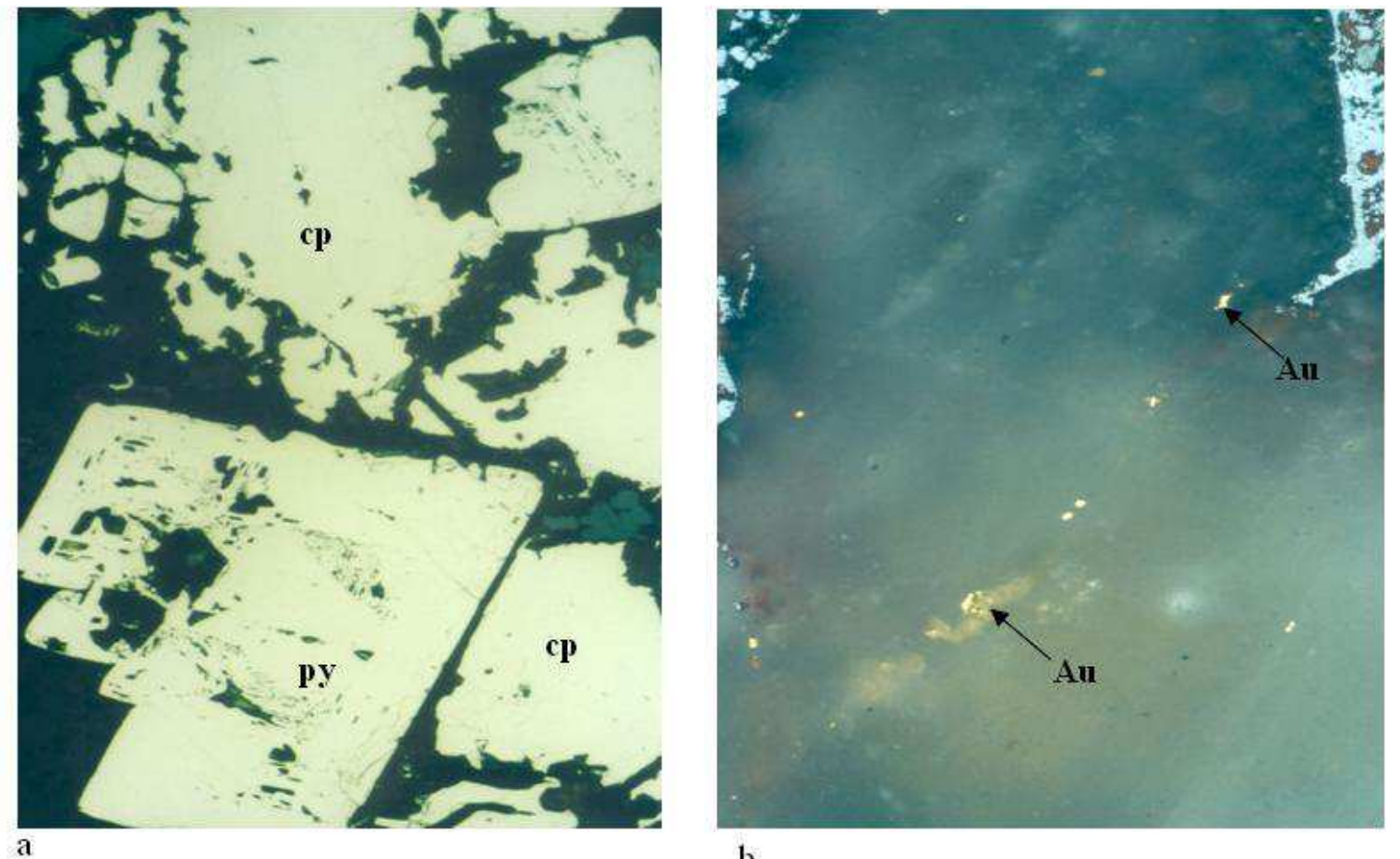

b

Figure 7. Photomicrographs for foliated and non-foliated GQV (a) pyrite (py) and chalcopyrite (cp) occurring in a zoned mineral assemblage (b) Au (yellow) occurring within micro fissures (fracture and foliation planes).

\subsubsection{Morphology and Au Chemistry}

Back Scattered Electro-microscopy (BSE) images for Au- grains obtained from $\mathrm{QV}_{2}$ show slight variation in the shapes and sizes of the grains (Fig. 8a-c). These grains vary from 
sub-rounded through sub-equant to tabular. The sub-rounded grains (Fig. 8a) have corroded margins and pitted surfaces. The sub-equant and tabular grains have smooth surfaces with indented margins. Sub-equant grains (Fig. 8c) have larger grain sizes of $348-392 \mu \mathrm{m}$, while the sub-rounded grains have smaller sizes $(\sim 102 \mu \mathrm{m})$. The chemistry of Au particles obtained from $\mathrm{QV}_{2}$ is indicated on the EDS spectra (Fig. 9ac). These spectra show that $\mathrm{Au}$ does not only occur as pure but also alloyed in small proportion with $\mathrm{Ag}$ as indicated by the presence of consistent small Ag peaks. The presence of $\mathrm{O}$, $\mathrm{Al}$ and $\mathrm{Si}$ peaks indicates the presence of sericite around the grains as hydrothermal alteration phases. The Fe peak is reminiscent of hematite with which $\mathrm{Au}$ is associated. Rutile

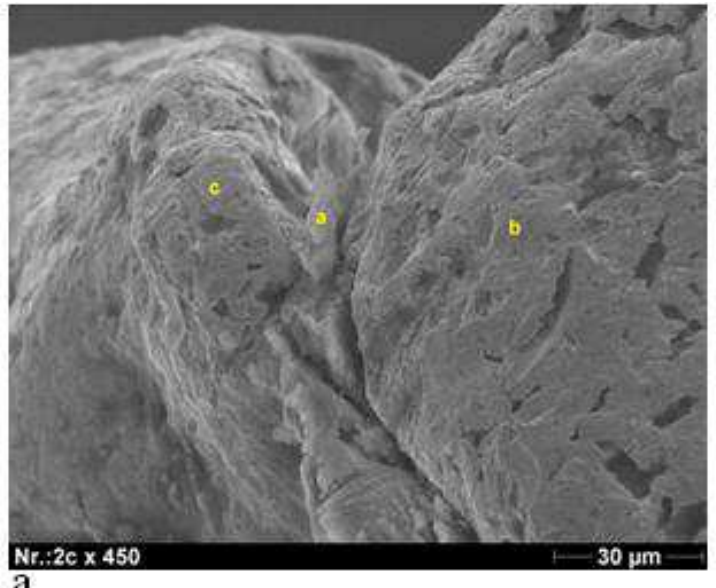

a

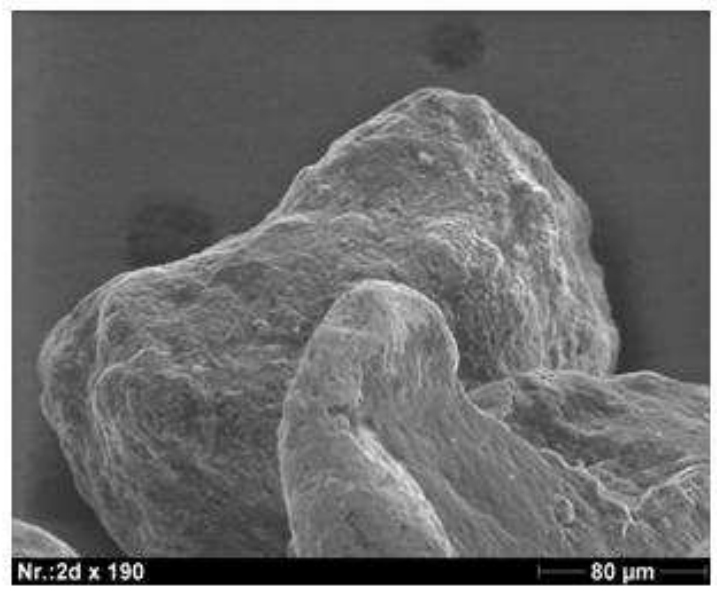

C particle also occur in the heavy mineral fraction (Fig. 9c). The association of $\mathrm{Ti}$ with $\mathrm{Fe}$ and $\mathrm{Ag}$ indicates a hydrothermal origin for Ti. This is explained by the presence of rutile grain in the heavy mineral fraction (Fig. 8d) with an EDS scan containing high peaks for Ti and Fe (Fig. 9c). The variation of mineral assemblage in GQV varieties suggests a situation of multiple deformation and fluid generation episodes. [13] Suggests that such a situation may indicate fluid immiscibility during $\mathrm{Au}$ deposition. However, the Aurich veins that highly contain iron oxide (hematite) seem to be different from $\mathrm{Au}$ chemistry from other $\mathrm{Au}$ districts of the Birimian [e.g.13, 40].
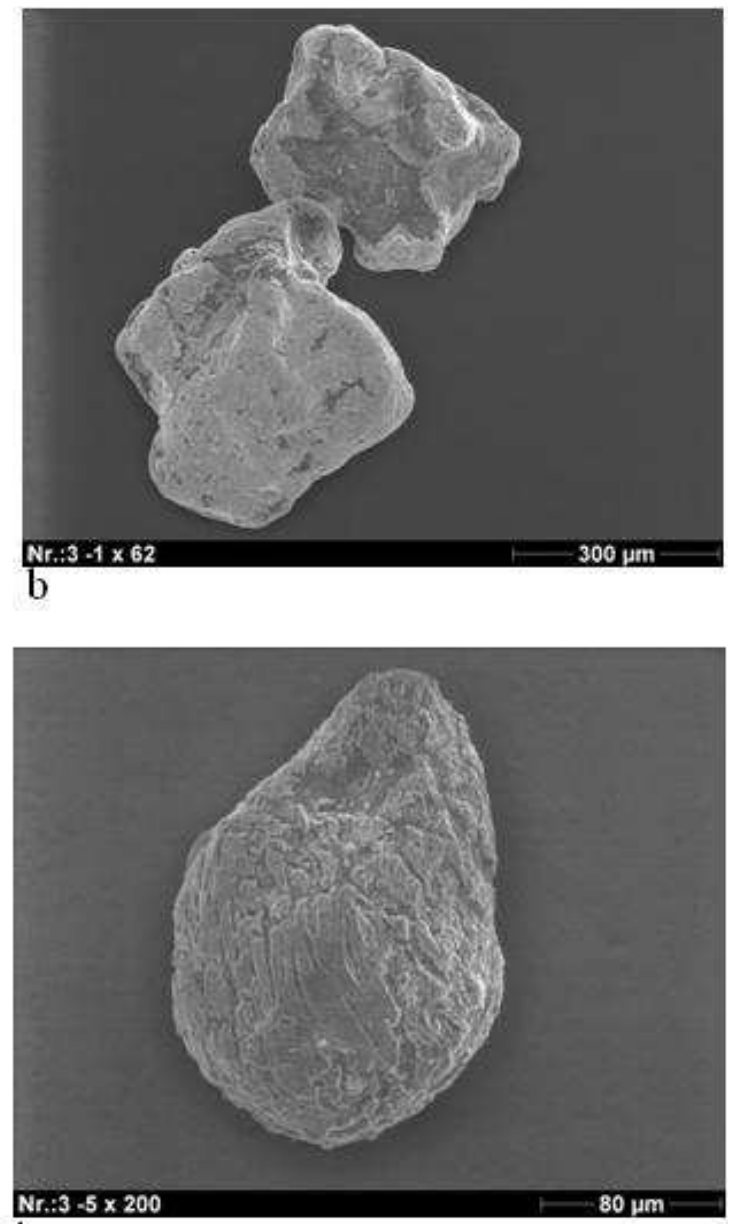

d

Figure 8. Photomicrographs of grains obtained from panning (a) sub-rounded grains with corroded margins and grain boundary located at point a (b) subequant grains with indented margins (c) tabular grains with indented margins and pitted surfaces (d) elongated rutile grain. 
(a)
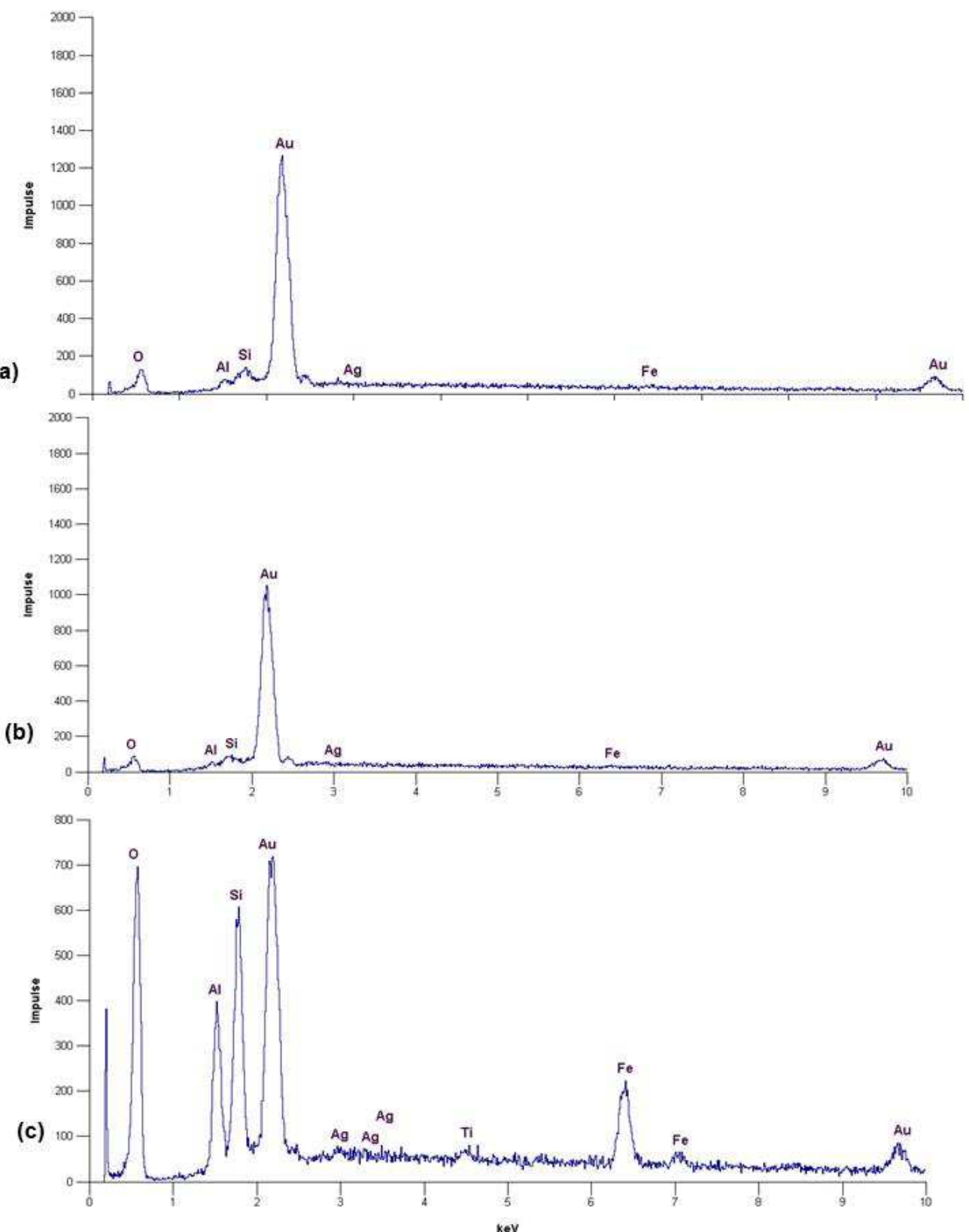

Figure. 9. EDS pattern for Au particles (a) pattern for Au at spot b (b) pattern for same grain at spot c away from grain boundary (c) pattern at spot $c$ that represents the grain boundary. Note small peaks of $\mathrm{Ag} \mathrm{Fe}$ and Ti.

\section{Conclusions}

Au-bearing quartz veins in the Batouri south area are confined to a major NNE and partly NNW orientations. These veins are characterized by partially and completely filled fractures and foliation planes. This therefore constitute the main mineralization style within the area. Disseminated $\mathrm{Au}$ is common in sheared weathered wall rock associated with veinlets and vein splays. Both foliated and non-foliated quartz veins (barren and mineralized) varieties occur in this area. The investigated veins show evidence of multiphase deformation as indicated by the mineralogical, textural and cross-cutting relationships among veins. However, a distinctive relict of hydrothermal wall rock alteration occurs along the quartz veins and veinlets that showing lateral zoning (weathered meta-granite $>$ pinkish zone $>$ light brown zone >reddish zone >bleached zone >ferruginised zone >quartz vein). Generally, the weathered wall rock envelope is poor in $\mathrm{Au}$. The bleaching in the weathered wall rock does not indicate mineralization as the field results (Table 1) shows the association of the zone with veins devoid of Au. Accessory minerals include: rutile and/or ilmenite, with quartz and sericite as the most common gangue mineral. The mineralized veins are rich in hematite and poor in pyrite /chalcopyrite. The chemistry of $\mathrm{Au}$ particles indicates the presence of gold with metals (Fe, Mn, Ag, Al), O, S and $\mathrm{Si}$ derived from supergene enrichment (sericitization). 


\section{Acknowledgements}

Special thanks go to African Aura Resources Ltd. (AAR) Cameroon, for providing the financial and research materials and paying for the analysis. We also the material support offered to us by the University of Buea for part of the analysis carried out.

\section{References}

[1] Pitfield, P.E.J., Campbell, D.G., 1996. Significance for Au exploration and structural style of auriferous deposits in the Archaean Bulawayo-Bubi greenstone belt of Zimbabwe; Transactions of Mining and Metallurgy, Section B. Applied Earth Sciences 105, 41-52.

[2] Catheline, M., Marignac, C., Boiron, M.C., Poty, B., 1991. Herynian Au bearing quartz veins from Western Europe: the "shear zone model" revisited. Proceeding of Au. Brazil Balkema 91, 115-119.

[3] Harraz, H.Z., 1999. Wall rock alteration, Atud Au Mine, Eastern Desert, Egypt: Process and P-T-X CO2 conditions for mineralization...Journal of African Earth Sciences 28, 527-551.

[4] Bouchot, V., Milesi, J.P., Ledru, P., Lerouge, C., Roig, J.Y., Bellot, J.P., Becq-Girdon, J.F., Truffert, C., 2000. OrogenicAu veins and W, Li-F mineralization related to "specialized" granites; two markers of the crustal scale -W. Sb metaliferous peak at 310-305 Ma (French Variscan Belt). In: A GEODEGEOFRANCE 3D workshop on orogenic $\mathrm{Au}$ deposits in Europe with emphasis on the Variscides, Bouchot, V., Moritz, R. (eds). Orleans, 53-55.

[5] Nicaud, J., Floc'h, J.P., 2000. Structural control of Au bearing quartz veins forming in the Saint Yrieix District (Massif Central France). In: A GEODE-GEOFRANCE 3D workshop on orogenic Au deposit in Europe with emphasis on the Variscides, Bouchot, V., Moritz, R. (eds), Orléans 71-72.

[6] Simard, M., Bedoin, G., Bernard, J., Hupé, A., 2006. Metallogeny of the Mont-de-L'Aigle IOCG deposit, Gaspé Peninsula, Québec, Canada. Mineralium Deposita 41, 607-636.

[7] Kreuzer, O.P., 2006. Textures, paragenesis and wall rock alteration of lode $\mathrm{Au}$ deposits in the Charter Towers district, North Queensland: implication for the conditions of ore formation. Mineralium Deposita 40, 639-663.

[8] Junks, A.J., Cooke, D.R., 2007. Geological and structural controls on Au mineralization in the Tanami district Northern Territory 42, 107-126.

[9] El Bouseily, A.M., El Dahhar, A., Arselan, A.I., 1985. Ore microscopy and geochemical characteristics of Au-bearing sulphide minerals, El Sid Au Mine, eastern Desert, Egypt. Mineralium Deposita 20, 194-200.

[10] Hilmy, M.E., Osman, A., 1989. Remobilization of Au from a chalcopyrite-pyrite mineralization, Hamash $\mathrm{Au}$ mine southeastern desert, Egypt. Mineralium Deposita 24, 244-249.

[11] Harraz, H.Z., Hassanen, M.A., El Dahhar, M.A., 1992. Fluid inclusions and stable isotopic studies at the El Sid Au mine, eastern Desert, Egypt. Egyptian Journal of Geology 36, 323343 .
[12] Williams, P.J., Barton, M.D., Johnson, D.A., Fontabe, L., de Haller, A., Mark, G., Oliver, N.H.S., Marshik, R., 2005. Iron oxide-copper-Au deposits. Geology, space, time, distribution and possible modes of origin. Economic Geology 100, 371405 .

[13] Coulibaly, Y., Boiron, M.C., Catheline, M., Kouamelan, A.N., 2008. Fluid immiscibility and Au deposition in the Birimian quartz veins of the Angoviadeposit (Yaouré, Ivory Coast). Journal of African Earth Sciences 50, 234-254.

[14] Barret, T.J., MacLean, W.H., 1994. Chemo-stratigraphy and hydrothermal alteration in exploration for VHM deposits in greenstone and younger volcanic rocks. In: Alteration and alteration process associated with ore forming systems, Lentz, D.R. (eds). Geological Association of Canada Short courses notes Toronto, Ontario 11, 433-467.

[15] Beirlein, F.P., Fuller, T., Stuwe, K., Arne, D.C., Keays, R.R., 1998. Wall rock alteration associated with turbidite-hosted $\mathrm{Au}$ deposit. Example from the Palaeozoic Lachlan fold belt in Central Victoria, stralia. Ore Geology Review 13, 345-380.

[16] Vallance, J., Boiron, M.C., Catheline, M., Verlet, M.,Marignac, C., 2004. The granitic hosted Au deposit of Moulin de Chéni (Saint Yrieix district, Massif Central France): petrography, structural, fluid inclusion and oxygen isotope constraints. Mineralium Deposita 39, 265-281.

[17] Suh, C.E. (2008): Sulphide microchemistry and hydrothermal fluid inclusion in quartz veins Batouri gold district (Southern Cameroon).journal of the Cameroon Academy of Science 8, 19-29.

[18] Sherlock, R.L., Barrett, T.J., Lewis, P.D., 2003. Geological setting of the Rapu Rapu Au-rich volcanogenic sulphide deposits, Albay Province, Phillippines. Mineralium Deposita $38,813-830$

[19] Kreuzer, O.P., 2003. Structure, timing and genesis of auriferous quartz veins in the Charters Towers Au field, north Queensland: implication for exploration and prospectively. $\mathrm{PhD}$ thesis, James Cook University, Townville.

[20] Oliver, N.H.S., Cleverley, J.S., Mark, G., Pollard, P.J., Fu, B., Marshall, L.J., Rubenach, M.J., Williams, P.J., Barker, T. 2004 Modeling the role of sodic alteration in the genesis of iron oxide-copper-Au deposits, eastern Mount Isa block, stralia. Economic Geology 99, 1145-1176.

[21] Haeberlin, Y., Moritz, R., Frontbote, L., Cosca, M., 2004. Carboniferous OrogenicAu deposits at Pataz, eastern Andean Cordillera, and Peru: geological and structural framework, paragenesis, alteration and 40Ar/39Ar geochronology. Economic Geology 99, 73-112.

[22] Toteu, S, F., Van schmus, W.R., Penaye, J.M. and Michard, A. (2001): New U-Pb and Sm-Nd data from north central Cameroon and its' bearing on the Pre-Pan-African history of Africa. Precambrian Research 108, 45-73.

[23] Ngako, V., Affaton, P., Nnange, J.M., Njanko, T.H., 2003. PanAfrican tectonic evolution in the central and southern Cameroon: trans-pression and trans-tension during sinistral shear movements. Journal of African Earth Sciences 36, 207214.

[24] Njonfang E., Ngako V., Moreau C., Affaton P., Diot H., 2008. Restraining bends in high temperature shear zones: The "Central Cameroon Shear Zone", Central, Africa Journal of African Earth Sciences 52, 9-20. 
[25] Hafner, B., 2006. Energy Dispersive Spectrometry on the SEM: a primer. Characterization Facility, University of Minnesota-Twin Cities, p26.

[26] Hoffman Eric, L., Clark John, R. \& Yeager James, R. 1998. Gold Analysis - Fire Assaying and Alternative Methods. Explor. Mining Geology, 7:155-160.

[27] Asaah, A. V., 2010. Lode gold mineralization in the Neoproterozoic granitoids of Batouri, southeastern Cameroon, $\mathrm{PhD}$ dissertation, Faculty of Energy and Economic Sciences, Clausthal University of Technology, p202.

[28] Brito Neves, B.B., Van Schmus, W.R., Fetter, A., 2002. North western, Africa-north, east Brazil: major tectonic links and correlation problems. Journal of African Earth Sciences 34, 275-278.

[29] Coutinho, M.G.N., Alderton, M.D.H., 1998. Character and genesis of Proterozoic shear zone-hosted $\mathrm{Au}$ deposit in Boborema Province, northeast Brazil. Transactions of the institution of Mining and Metallurgy. Section B, Applied Earth Science 107, 66-109.

[30] Klein, E.L., Alves dos Santos, R., Fuzikawa, K., Angelica, R.S., 2001. Hydrothermal fluid evolution and structural control of the Guarim Au mineralization, Tapajos Province, Amazonian craton, Brazil. Mineralium Deposita 36, 149-164.

[31] Rhys, D., DiMarchi, J., Smith, M., Friesen, R., Rombach, C., 2003. Structural setting, style and timing of vein-hosted $\mathrm{Au}$ mineralization at the Pogo Deposit, east central Alaska. Mineralium Deposita 38, 863-875.

[32] McCuaing, T.C., Kerrich, R., 1998. P-T-t deformation fluid characteristics of lode $\mathrm{Au}$ deposits; evidence from alteration systematics. Ore Geology Review 12, 381-453.

[33] Boiron, M.C., Barakat, A., Catheline, M., Banks, D.A., Durisova, J., Moravek, P., 2001. Geometry and surficial fluids during the uplift of the Hercynianupper crust: consequence for Au deposition. Chemical Geology 173, 207-225.

[34] Tourigny, G., Tremblay, A., 1997. Origin and incremental evolution of brittle/ductile shear zone in granitic rocks: natural examples from the southern Abitibi Belt, Canada. Journal of Structural Geology 19, 15-27.

[35] Robert, Boullier, A.M., Firdaous, K., 1995.Au quartz veins in metamorphic terranes and their bearing on the role of fluids in faulting. Journal of Geophysical Research 100 (B7), 1286112879 .

[36] Murphy, P.J., Roberts, S., 1997. Evolution of a metamorphic fluid and its role in lode $\mathrm{Au}$ mineralization in the central Iberian Zone. Mineralium Deposita 28,469-481.

[37] Hagemann, S.G., Groves, D.I., Ridley, J.R.,Vearncombe, J.R., 1992. The Archaean lode Au deposits. European Journal of Mineralogy 8, 937-960.

[38] Jebrak, M., 1997. Hydrothermal breccias in vein-type ore deposit: a review of mechanism, morphology and size distribution. Ore Geology Review 12, 1127-1136.

[39] Sibson, R.H., 2004. Control on maximum fluid overpressure defining conditions for mesothermal mineralization. Journal of Structural Geology 26, 1127-1136.

[40] Stendal, H., Frei, R., Hamilton, M.A., Mueller, W.U., 2001. The Palaeoproterozoic Kangerluluk Au-copper mineralization (southeastern Greenland): $\mathrm{Pb}$ and $\mathrm{Nd}$ isotopic constraints on its timing and genesis. Mineralium Deposita 36, 177-188. 